\title{
The Effect of Case-Based Curriculum on Cognitive and Affective Characteristics of Students*
}

\author{
Dilek İlhan-Beyaztaş ${ }^{1}$, Burhanettin Özdemir ${ }^{2}$ \\ ${ }^{1}$ Faculty of Education, Erzincan University, Erzincan, Turkey \\ ${ }^{2}$ Faculty of Education, Siirt University, Siirt, Turkey \\ Correspondence: Dilek İlhan-Beyaztaş, Faculty of Education, Erzincan University, Erzincan, Turkey.
}

Received: January 11, 2018

Accepted: February 5, $2018 \quad$ Online Published: February 15, 2018

doi:10.11114/jets.v6i3.3035

URL: https://doi.org/10.11114/jets.v6i3.3035

\begin{abstract}
This study aims to determine the effect of case-based curriculum (CBC) on the cognitive and affective characteristics of the pre-service teachers. The case-based curriculum was developed within the scope of the "Introduction to Educational Science" course at the university level. It was applied to experimental groups by two different methods that are CBL1 and CBL2, respectively. The CBL1 was implemented through the presentation of the unit subjects, applying the teaching strategy and using the cases, while CBL2 was implemented by ensuring students to reach information through the cases rather than the presentation of the unit subjects by the instructor. The study used a mixed method approach which employed the semi-experimental methods for data collection using pretest-posttest control group design. The study group consists of 334 freshmen taking the "Introduction to Educational Science" course, of education faculties of two different universities. The purposive sampling technique was used to select these students. The result of the study indicates that there was a significant difference in the course "introduction to educational sciences" in favor of the experimental groups in terms of their learning levels. In interviews with students; it has been found that case-based learning (CBL) techniques have a positive impact on students' socialization and communication skills development, and support cooperation. In addition, a large majority of the students stated that CBL contributes to their interest to the course as well as their awareness towards and adoption of the teaching profession. Therefore, CBL can be taken as a basis for developing curricula and the effectiveness of these curricula can be viewed in terms of improving the cognitive, social and affective skills of students.
\end{abstract}

Keywords: case-based curriculum, cognitive characteristics, affective characteristics, educational assessment

\section{Introduction}

The era which we live in expresses that the basic production factor is information, and emphasizes the importance of being an information society. Within the scope of rapidly changing and developing technology and the new requirements brought by it, information society brings the production, usage and management of information in the forefront. In this context, information society emphasizes the individuals who find, process, produce and create the right knowledge and this process can only be managed by individuals who have learned effective learning and gained high-level thinking skills (İlhan-Beyaztaş, 2014). Accordingly, it is important for pre-service teachers who are candidates to raise individuals carrying the abovementioned characteristics at the level of higher education to design the curricula in which the teaching process is student centered and high level thinking skills are required. One of these curricula is case-based learning $(\mathrm{CBL})$ which involves students working individually or in groups on problem situations. Case-based learning; is a learning and teaching method in which analytical thinking skills are put into practice by problem solving and decision making skills through real-like problems (Elksnin, 1998, p. 96; Levin 1995, p. 63; McWilliam, 1992, p. 362-363; Smith, 1987, p. 51).

Although similar results were obtained with respect to acquisition of students, it is possible to come across different CBL practices and classifications in the literature (Barrows, 1986, Herreid, 1994). According to Wassermann (1994), despite various practices, fundamental elements of the CBL process are;

${ }^{*}$ This study was supported by the Coordinatorship of the Scientific Research Projects at Erzincan University under Grant number 413. 
1. Cases: Narrative situations in which students and teachers work collaboratively.

2. Study Questions: At the end of each case, questions towards high-level thinking skills are asked.

3. Small Group Works: Cases are discussed by a small group to find possible solutions.

4. Class Discussions: Discussion of the case with the participation of the whole class after small group work.

5. Activities to Ensure Permanence: In class discussions, students are guided to learn more if the answer is not fully attained.

According to the literature; CBL is effective on improving academic success of students (Adiga \&Adiga, 2011; Brown, Pond, \& Creekmore, 2011; Ciraj, Vinod, \& Ramnarayan, 2010), improving problem-solving skills (Choi and Lee, 2009; Roche, Aitken and Zito, 1999), improving the effectiveness of group work (Flynn and Klein, 2001; Levin, 1995, Weil, McGuigan \& Kern, 2011) and preparing students to professional life and improving high-level thinking skills (Alvarez, 1990; Biggs \& Tang, 2007; Bowie, Voss \& Aretz, 2009; Fossey, 2006; McNaught, Lau, Lam, Hui \& Au, 2005, Milner \& Wolfer, 2014). In this scope, it is observed that the studies related to CBL within the country are limited to only discussing the issue at the primary and secondary education level and its effect on the students' academic achievement (Adal1, 2005, Çam, 2009, Horzum \& Alper, 2006, Saral, 2008, Yalçınkaya, 2010). In addition, studies on teacher education at the level of higher education seem to be limited.

In this context, it is necessary to examine the effectiveness of CBL through case-based curriculum developed in teaching profession which is among the applied science fields. This study is believed to contribute to closing the gap between theory and practice that can occur in pre-service teachers and to raise more qualified pre-service teachers.

In this context, the following questions will be answered within the scope of the research:

1. How do the experimental groups in which the CBL1 and CBL2 technique is applied, and the control groups differ with respect to entrance knowledge of course?

2. How do the experimental groups in which the CBL1 and CBL2 technique is applied, and the control groups differ with respect to acquisition level?

3. Is there a significant difference between the first experimental group in which the CBL1 technique is applied and the second experimental group in which the CBL2 technique is applied, and the acquisition levels of the students in the control groups in terms of entrance knowledge of the course "introduction to educational science"?

4. What are the opinions of the students on the contribution of the case-based curriculum to the acquisition of cognitive skills, affective characteristics and social skills in the course "introduction to educational science"?

\section{Method}

The study used a mixed method approach which employed the semi-experimental methods for data collection using pretest-posttest control group design. In the scope of the study, the case-based curriculum was applied to experimental groups by two different methods. In this scope, the first and the second experimental groups assigned randomly and called "the first experiment group (CBL1)" and "the second experimental group (CBL2)", respectively. In the first experimental group; case-based curriculum developed within the scope of the research was implemented through the presentation of the unit subjects, applying the teaching strategy and using the cases (CBL1). In the second experiment group; case-based curriculum developed within the scope of the research was implemented by ensuring students to reach information through the cases rather than the presentation of the unit subjects by the instructor (CBL2). Conventional education was maintained in the control groups. In addition, within the scope of qualitative data collection related to CBL1 and CBL2 practices; a semi-structured interview was conducted with 11 voluntary students from the first experimental group and 9 voluntary students from the second experimental group.

\subsection{Research Group}

The convenience sampling method was used to select study group that consists of 334 freshmen in education faculties of two different universities taking the "Introduction to Educational Science" course. Experimental groups of the study consist of Branch A students from the Department of Classroom Teaching at Erzincan University (48- 14.4\%) and Branch B students (48-14.4\%). The control groups consist of students from the Departments of Social Studies Teaching (38- 11.4\%), Preschool Teaching (40-12\%), Mathematics Teaching (41- 12.2\%) and Guidance and Psychological Counseling Students (43-12.8\%). In addition, in order to control the department effect in the study, branch A student from the Department of Classroom Teaching at Siirt University (35-\% 10.4) and branch B students (41-\% 12.2) were also included in the study group as they were in the same department as the control groups. At the beginning of the research, high school diploma grades were used to determine whether the students in the experimental and control groups were cognitively equal via a statistical test called one-way ANOVA (Analysis of Variance). The ANOVA is a 
parametric test that compares the means of different subgroups associated with measured variable in order to determine significant difference between subgroups. The ANOVA results showed that there was no significant difference between high school diploma grades of the students in their experiment and control groups $(\mathrm{p}>0.05)$.

\subsection{Experimental Processing Steps}

Within the scope of the research, first of all, Introduction to Educational Sciences curriculum was designed by taking CBL approach as a basis. For designing the curriculum of the Introduction to Educational Science course, the current scope of the course was examined and the content of the course was created as a result of the work conducted with field experts. Within the framework of the course, Bloom's Cognitive Domain Taxonomy was taken as a basis; and goals and target behaviors were determined. The specified goals and target behaviors were examined by three program development experts and the necessary arrangements were made within the framework of the feedbacks. Two different techniques prepared within the scope of the study as follows; CBL1 (Step 1: Teaching Through Presentation, Step 2: Case Examination and Step 3: Case Discussion and Revision), and CBL 2 (Step 1: Case Examination, Step 2: Case Discussion and Step 3: Teaching Through Presentation).

\subsection{Data Collection Tools}

\subsubsection{Acquisition Test}

In this study, acquisition test, which indicates to what extend students have developed their skills throughout the program, was used to collect quantitative data. Within the framework of the course "Introduction to Educational Science", Bloom's Cognitive Domain Taxonomy was taken as a basis and; goals and related target behaviors were determined. A table of specification had been prepared before the items were written for the acquisition test, and this table was used as a criterion for the items prepared throughout the whole process. For items to be used in the acquisition test, the literature was reviewed and 100 items were written. Two field experts, three program development specialists and an assessment-evaluation expert have been consulted on content validity of the table of specification, understandability of the question items, quality of the questions and whether these items question the presence of related behaviors. The necessary adjustments have been made within the light of the feedbacks of the experts. The prepared sample test was applied to 334 second year students who took the same course in the previous year in the fall semester of 2016-2017 academic year. The sample test data including multiple-choice questions were analyzed using the $\mathrm{R}$ program. At the end of the item analysis, fifty items, which had acceptable item difficulty and discrimination parameters, were selected and the final test was developed. The KR-20 internal consistency reliability coefficient of the final test was found to be 0.82 .

\subsubsection{Student Interview Form}

Semi-structured interview form was prepared in order to obtain student's views on the practice of the case-based curriculum in the Introduction to Educational Science course which is assumed to provide insight into ANOVA results. In order to determine the suitability of the prepared interview questions for the purpose of the research, three program development experts and two assessment-evaluation experts were consulted and a draft interview form was prepared by making the necessary arrangements according to the feedbacks. Three students were interviewed to determine the suitability of the prepared draft form in terms of service and comprehensibility. Within the light of the suggestions from the students, necessary corrections were made on the interview questions and the final form was given to the interview by re-interviewing with three program development experts and an assessment-evaluation specialist to finalize the draft form.

The main interview was conducted with 11 voluntary students from the first experimental group and 9 voluntary students from the second experimental group. Semi-structured interviews conducted with participants were recorded with the permission of the participants. The recorded interviews were transcripted by the researchers and then evaluated via content analysis which is defined as "a scientific approach examining social reality through objectively and systematically classifying, digitizing, and deducing the message contained in verbal, written and other materials in terms of meaning and / or grammar" (Tavşancıl \& Aslan, p.22). Descriptive analysis was also conducted to better reflect the current situation. For the content analysis and descriptive analysis, the codes were determined by examining all the data and the themes were created based on the codes. The data were re-read and rearranged according to the determined codes and themes; and supported directly by quotes.

In order to ensure internal validity, the qualitative data were continuously discussed and critically examined with a field expert. The codes and themes resulting from the reviews were examined by two field experts and finalized according to the feedback they gave. According to Yıldırım \& Şimşek (2008, p.260), within the scope of providing external validity, the qualitative researcher needs to inform readers in detail about all the steps of the research in order to generalize the results to similar environments. In this context, detailed explanations are provided on the steps and results of the research in order to achieve external validity. 
In order to ensure internal reliability in qualitative data, the "Observation-Based Reliability" method, which means that more than one researcher measure a phenomenon or event in the same way, was applied and an internal reliability study was conducted with two field experts to this end. For the external reliability, the "Time Dependent Reliability" method was used to express the consistency of the measurement in the same way over time. In this context, the external reliability study was conducted with two field experts with a fifteen-day interval (Kirk \& Miller, 1986, cited by. Yıldırım \& Şimşek, 2008, p. 260). In addition, Miles and Huberman (1994) suggests the following formula for the reliability measurement:

Agreement Number

$$
\text { Reliability }=\longrightarrow \text { Agreement }+ \text { Disagreement Number }
$$

Within the scope of the abovementioned formula, the codes were detected in accordance with a field expert's reading of the data of three students and the consistency was detected as 0.86 by the researchers (coders)

\section{Findings and Discussion}

The first sub-problem of the research is to answer the question if there is a significant difference between the first experimental group in which the CBL1 technique is applied and the second experimental group in which the CBL2 technique is applied, and the learning levels of the students in the control groups in terms of entrance knowledge in the course "introduction to educational science. In this context, descriptive statistics related to students' pre-test scores of introduction to the educational sciences course, which provide insight into equivalence of students' entrance knowledge with respect to given course, are presented in Table 1.

Table 1. Descriptive statistics related to pre-test scores of the experimental and control group

\begin{tabular}{|c|c|c|c|c|c|c|}
\hline Department & Group & $\begin{array}{l}\text { Student Number } \\
(\mathrm{N})\end{array}$ & Mean & $\begin{array}{l}\text { Standard } \\
\text { d. }\end{array}$ & Skewness & Kurtosis \\
\hline Department of Classroom Teaching & $\begin{array}{l}\text { Experiment } \\
\text { (CBL1) }\end{array}$ & 48 & 47.25 & $(6.90)$ & .809 & .490 \\
\hline Department of Classroom Teaching & $\begin{array}{l}\text { Experiment } \\
\text { (CBL2) }\end{array}$ & 48 & 45.92 & 7.58 & -.638 & .099 \\
\hline Department of Classroom Teaching & Control & 35 & 48.42 & 8.11 & -.025 & -.549 \\
\hline Department of Classroom Teaching & Control & 41 & 48.34 & 8.51 & -.151 & -.571 \\
\hline Department of Social Studies & Control & 38 & 46.74 & 9.06 & .172 & -.758 \\
\hline Department of Pre-School Teaching & Control & 40 & 48.00 & 8.16 & .417 & .656 \\
\hline Department of Mathematics Teaching & Control & 41 & 46.15 & 10.30 & -.593 & .503 \\
\hline $\begin{array}{l}\text { Department of Psychological Counseling and } \\
\text { Guidance }\end{array}$ & Control & 43 & 48.60 & 9.28 & .146 & -.917 \\
\hline
\end{tabular}

When the descriptive statistics of the pre-test scores of the departments presented in Table 1 are examined, it is seen that the mean scores of the departments vary between 45.92-48.60 and the standard deviations vary between 6.90-10.30. In addition, the number of students who take the pre-test seems to be higher than 30 . Therefore, mean difference between pre-test scores of the departments was examined by one-way ANOVA method. Before performing the ANOVA test, the normality, linearity, and homogeneity assumptions of parametric tests were tested.

The assumptions of normality of the pre-test scores of each department and the homogeneity of variances were examined by Kolmogorov-Smirnov normality test and Levene homogeneity test, respectively. According to the results of the analysis, the distribution of the pre-test scores related to the different departments is normal and the respective variances are homogeneous (Levene test, $\mathrm{p}=0.279>0.05$ ). When the skewness and kurtosis coefficients of the pre-test scores of the departments are examined, one can observe that the coefficients of skewness and kurtosis of the departments vary within the range of \pm 1 except for the Department of Mathematics Teaching. It is seen that the coefficient of skewness of the department of mathematics is close to 1 . According to these findings, it can be said that the pre-test scores of each department are normally distributed. It is also assumed that the assumption of linearity is provided in cases where the assumptions of normality and homogeneity are satisfied. After the assumptions of normality, homogeneity and linearity were satisfied one-way ANOVA test was applied to detect if there is a significant difference between the pre-test scores of the departments. Table 2 presents the results of one-way ANOVA for the pre-test scores of the departments. 
Table 2. One-way ANOVA results for the pre-test scores of the departments

\begin{tabular}{lccccc}
\hline & Sum of Squares & $\begin{array}{c}\text { Degree of } \\
\text { Freedom }\end{array}$ & Mean square & F-statistics & $\begin{array}{c}\text { Significance level } \\
(\mathrm{p})\end{array}$ \\
\hline Intra-group & 337.950 & 7 & 48.279 & 0.667 & 0.700 \\
Inter-group & 23581.227 & 326 & 72.335 & & \\
Total & 23919.177 & 333 & & & \\
\hline
\end{tabular}

The one-way ANOVA results of the pre-test scores of the departments presented in Table 2 shows that there is no significant difference between the mean pre-test scores of the departments $(F(7,326)=0.667, p=0.70>0.05)$. Therefore, it has been concluded that there is no significant difference between the first experimental group that the CBL1 technique is applied and the second experimental group that the CBL2 technique is applied, and the learning levels of the students in the control groups in terms of entrance knowledge in the course "introduction to educational science".

The second sub-problem of the research is to answer the question; "Is there a significant difference between the first experimental group in which the CBL1 technique is applied and the second experimental group in which the CBL2 technique is applied, and the acquisition levels of the students in the control groups in terms of entrance knowledge in the course "introduction to educational science"? In this context, descriptive statistics related to students' post-test scores in the introduction to the educational sciences course are presented in Table 3.

Table 3. Descriptive statistics related to post-test scores of the experimental and control group

\begin{tabular}{|c|c|c|c|c|c|c|}
\hline Department & Group & $\begin{array}{l}\text { Student } \\
\text { Number } \\
(\mathrm{N})\end{array}$ & Mean & $\begin{array}{l}\text { Standard } \\
\text { deviation }\end{array}$ & Skewness & Kurtosis \\
\hline Department of Classroom Teaching & $\begin{array}{l}\text { Experiment } \\
\quad(\mathrm{CBL} 1)\end{array}$ & 48 & 66.00 & 8.66 & -.619 & -.477 \\
\hline Department of Classroom Teaching & $\begin{array}{l}\text { Experiment } \\
\text { (CBL2) }\end{array}$ & 48 & 64.58 & 10.31 & -.414 & .361 \\
\hline Department of Classroom Teaching & Control & 35 & 57.31 & 7.19 & -.363 & .105 \\
\hline Department of Classroom Teaching & Control & 41 & 59.37 & 7.57 & .116 & .200 \\
\hline Department of Social Studies & Control & 20 & 48.90 & 8.84 & .129 & 1.112 \\
\hline Department of Pre-School Teaching & Control & 20 & 50.18 & 10.20 & .312 & -.619 \\
\hline Department of Mathematics Teaching & Control & 20 & 49.50 & 15.46 & -1.259 & .316 \\
\hline $\begin{array}{l}\text { Department of Psychological Counseling } \\
\text { and Guidance }\end{array}$ & Control & 32 & 60.68 & 5.06 & -.002 & -.961 \\
\hline
\end{tabular}

When the descriptive statistics related to the post-test scores of the departments presented in Table 3 are examined, it is seen that the number of students who took the post-test in some departments is less than 30 Therefore, t-test and Wilcoxon signed ranks test were used in paired samples to detect whether there is a significant difference between the pre-test and post-test scores of first experimental group in which the CBL1 technique is applied and the second experimental group in which the CBL2 technique is applied in the course "introduction to educational science". The paired sample t-test was used to detect whether there is a significant difference between the pre-test and post-test scores in groups (Experimental group-1, Experimental group-2, Branch-A, Branch-B, Department of Psychological Counseling and Guidance) having more than 30 students who took both tests in the experimental and control groups. However, the difference between the pre-test and post-test scores in groups with a student number less than 30 (social studies, mathematics and pre-school) was tested by non-parametric Wilcoxon signed rank test method. Table 3 presents the results of t-test and Wilcoxon signed rank test in paired samples, which show whether the difference between pre-test and post-test scores for each department is significant.

The findings in Table 4 indicates that the results of t-test on the difference between pre-test and post-test scores of the experiment-1 and experiment-2 groups, department of psychological counseling and guidance, classroom teaching branch- A and branch-B were significant. On the other hand, the results of the Wilcoxon signed rank-difference test on the difference between pre-test and post-test scores of the departments of mathematics teaching, pre-school and social studies teaching are not significant. In addition, it was found that the difference between the mean pre-test and post-test scores for the experimental groups were higher compared to the other departments. However, this finding does not provide sufficient evidence that CBL-1 and CBL-2 techniques offer a more effective learning environment than the traditional methods. Therefore, one-way ANOVA method was used to detect whether there is a significant difference between post-test scores of each department having a significant difference between the pre-test and post-test scores and the post-test scores of the experimental groups on which CBL-1 and CBL-2 techniques were used. 
Table 4. Significance test results of the pre-test and posttest difference in correlated samples

\begin{tabular}{|c|c|c|c|c|c|c|c|}
\hline Department & $\begin{array}{l}\text { Statistical } \\
\text { Test }\end{array}$ & $\begin{array}{c}\text { Number of } \\
\text { Individuals }(\mathrm{N})\end{array}$ & $\begin{array}{c}\text { Pre-test/Post-test mean } \\
\text { difference }\end{array}$ & t-statistics & z-statistics & $\mathrm{df}$ & $\begin{array}{c}\mathrm{p} \\
\text { value }\end{array}$ \\
\hline Experiment-1 & $\begin{array}{l}\text { Correlated } \\
\text { t-test }\end{array}$ & 48 & 18.75 & 13.934 & & 47 & 0.000 \\
\hline Experiment-2 & $\begin{array}{l}\text { Correlated } \\
\text { t-test }\end{array}$ & 48 & 18.67 & 12.847 & & 47 & 0.000 \\
\hline $\begin{array}{l}\text { Department of Psychological } \\
\text { Counseling and Guidance }\end{array}$ & $\begin{array}{l}\text { Correlated } \\
\text { t-test }\end{array}$ & 32 & 8.00 & 6.177 & & 31 & 0.000 \\
\hline Siirt Branch-A & $\begin{array}{l}\text { Correlated } \\
\text { t-test }\end{array}$ & 35 & 8.89 & 5.617 & & 34 & 0.000 \\
\hline Siirt Branch-B & $\begin{array}{l}\text { Correlated } \\
\text { t-test }\end{array}$ & 41 & 9.54 & 7.399 & & 40 & 0.000 \\
\hline Mathematics & $\begin{array}{l}\text { Wilcoxon } \\
\text { test }\end{array}$ & 20 & 4.90 & & 1.756 & & 0.079 \\
\hline Pre-school & $\begin{array}{l}\text { Wilcoxon } \\
\text { test }\end{array}$ & 22 & 1.90 & & 0.786 & & 0.432 \\
\hline Social Studies & $\begin{array}{l}\text { Wilcoxon } \\
\text { test }\end{array}$ & 20 & 2.03 & & .020 & & 0.984 \\
\hline
\end{tabular}

The assumptions of normality of the post-test scores of each department and the homogeneity of variances were examined by Kolmogorov-Smirnow normality test and Levene homogeneity test, respectively. According to the results of the analysis, the distribution of the post-test scores belonging to the different departments is normal and the respective variances are homogeneous. When the skewness and kurtosis coefficients of the post-test scores of the departments are examined, it is seen that the coefficients of skewness and kurtosis of the departments vary within the range of within \pm 1 except for the department of social studies teaching. It is seen that the coefficient of kurtosis of the department of social studies is close to 1 (1.12). After the assumptions of normality, homogeneity and linearity of the post-test scores of each department were satisfied, one-way ANOVA test was applied to detect whether there is a significant difference between the post-test scores of the departments. Table 5 presents the results of one-way ANOVA for the post-test scores of the experimental and control groups.

Table 5. One-way ANOVA results for the post-test scores of the departments

\begin{tabular}{llllll}
\hline Variance source & $\begin{array}{l}\text { Sum of } \\
\text { Squares }\end{array}$ & SD & Mean of squares & F & p value \\
\hline Inter-group & 2196.384 & 4 & 549.096 & 8.063 & .000 \\
Intra-group & 13551.597 & 199 & 68.098 & & \\
Total & 15747.981 & 203 & & & \\
\hline
\end{tabular}

According to results in Table 5, there was a statistically significant difference between the post-test scores of at least two departments according to the one-way ANOVA results on the post-test scores of the departments presented in Table $5\left(\mathrm{~F}_{4-199}=8.063, \mathrm{p}=0.00<0.05\right)$. The significant difference between the groups was analyzed by Fisher's LSD (least significant difference) test among post hoc tests. Table 6 presents the results of one-way ANOVA to determine whether there is a significant difference between the post-test mean scores of the different departments in the experimental and control groups.

Table 6. ANOVA test results for the post-test scores of the experimental and control groups

\begin{tabular}{|c|c|c|c|c|}
\hline Group-1 & Group-2 & $\begin{array}{c}\text { Difference between } \\
\text { means } \\
(1-2) \\
\end{array}$ & $\begin{array}{l}\text { Standard } \\
\text { deviation }\end{array}$ & $\mathrm{p}$ value \\
\hline \multirow{4}{*}{ CBL-1experimental group } & \multirow{3}{*}{ Counseling and } & 1.417 & 1.684 & 0.401 \\
\hline & & 5.313 & 1.883 & 0.005 \\
\hline & & 8.685 & 1.834 & 0.000 \\
\hline & Siirt Branch-B & 6.634 & 1.755 & 0.000 \\
\hline \multirow{4}{*}{ CBL-2 experimental group } & \multirow{4}{*}{ Counseling and } & -1.417 & 1.68447 & ,401 \\
\hline & & 3.896 & 1.88329 & 0.040 \\
\hline & & 7.269 & 1.83423 & 0.000 \\
\hline & & 5.217 & 1.75490 & 0.003 \\
\hline
\end{tabular}

When the one-way ANOVA results in Table 6 shows that the difference between the post-test scores of the CBL-1 experimental group and CBL-2 experimental group was not statistically significant $(\mathrm{p}=0.401>0.05)$. However, the 
difference between the post-test scores of the CBL-1 experimental group and the other control groups (Siirt University, Classroom teaching Branch-A, Siirt University, Classroom teaching, Branch-B and Department of Psychological Counseling and Guidance) was found statistically significant. Similarly, it was found that the difference between the post-test scores of the CBL-2 experimental group and the control groups was statistically significant. Although the post-test scores of the CBL-1 experimental group were higher than the CBL-2 experimental group, this difference was not statistically significant. According to these findings, it can be said that more effective teaching was achieved for the course "introduction to educational sciences" in classes where both the CBL-1 and CBL-2 techniques were applied compared to the classes where traditional methods were applied.

The fourth sub-problem of the research is related to the question "What are the opinions of the students on the contribution of the Case-Based Curriculum to the acquisition of cognitive skills, affective characteristics and social skills in the "introduction to educational science" course? In this context, the content analysis of qualitative data on the opinions of students was classified under the themes of "Cognitive Impact", "Affective Impact" and "Social Impact".

\subsection{Cognitive Impact}

Among the students' opinions on the practice of the case-based curriculum in the introduction to educational sciences course, the opinions obtained from the student interviews on the theme of "Cognitive Impact" and the frequency of these opinions are presented in Table 7.

Table 7. The opinions of the students on the cognitive impact of case-based curriculum and their frequency

\begin{tabular}{|c|c|c|c|c|c|c|c|}
\hline \multirow[t]{2}{*}{ THEME } & \multirow[t]{2}{*}{ CODES } & \multicolumn{2}{|c|}{$\begin{array}{l}\text { CBL1 } \\
(\mathrm{n}: 11) \\
\end{array}$} & \multicolumn{2}{|c|}{$\begin{array}{l}\text { CBL2 } \\
(\mathrm{n}: 9)\end{array}$} & \multicolumn{2}{|c|}{$\begin{array}{c}\text { Total } \\
(\mathrm{n}: 20) \\
\end{array}$} \\
\hline & & f & $\%$ & f & $\%$ & $\mathrm{f}$ & $\%$ \\
\hline \multirow{7}{*}{$\begin{array}{c}\text { Cognitive } \\
\text { Impact }\end{array}$} & Meaningful learning & 4 & 20 & 6 & 30 & 10 & 50 \\
\hline & Improving and steering the research skills & 3 & 15 & 6 & 30 & 9 & 45 \\
\hline & Permanent learning & 4 & 20 & 5 & 25 & 9 & 45 \\
\hline & Ensuring student participation & 2 & 10 & 4 & 20 & 6 & 30 \\
\hline & Interpretation skills & 3 & 15 & 2 & 10 & 5 & 25 \\
\hline & Practical learning by living & - & - & 3 & 15 & 3 & 15 \\
\hline & Problem in time use & - & - & 5 & 25 & 5 & 25 \\
\hline
\end{tabular}

When Table 7 is examined, $10(50 \%)$ of the 20 students expressed that CBL contributed to meaningful learning, and 9 $(45 \%)$ stated that their learning was more permanent and steered them to research. In addition, 6 out of 20 students $(30 \%)$ stated that they actively participated in the process with CBL and $5(25 \%)$ stated that CBL improved their interpretation skills. When the frequencies of CBL-1 and CBL-2 were compared, frequencies of the CBL-2 practice were observed to be higher. However, 5 (25\%) students from the CBL-2 group stated that they had problems in managing time effectively.

\subsubsection{Students' Statements Regarding Cognitive Impact}

When the opinions of the students are examined, contrary to traditional learning environments, they pointed out that the CBL activates increase the interest in the lesson. They also stated that it facilitated their learning and provided the permanence of knowledge. Direct citations obtained from the views of the students are given below.

Female (CBL-1)

"... It helped us to reinforce the information we had learned in the course. We understood better the information given in the course through the examples given in the cases, so that the information given during the classroom remained in our minds. I like the logic-based education in case-based curriculum instead of memorizing based teaching and I like the discussions held during the course.

Male (CBL-1)

"... The course "introduction to the educational sciences" was generally good, not only the lesson was instructed, but also constant comments and discussions about the subjects made the course both fast and pleasant. Thanks to the cases, I was able to see what I really understood from the course as I felt like the subjects were repeated. In addition, I better comprehended the subject thanks to the examples in the cases...."

Female (CBL-2)

“...The course was nice, fun and satisfactory. I absolutely believe that it was a productive course. A course that we cannot build in our mind to imagine cannot bring any contribution. After the exam, what we learn burst like a bubble. Case-based courses are more effective since we can envisage the concepts, terms and events based on the experience. Because, the student should not mean to sit down and listen 
what is instructed. A student should be a researcher. I felt like reaching to the status of student by means of the cases. Making research is obligatory rather than listening to the information. I felt like a student, a wolf that is hungry for more information. I enjoyed seeking for new things when I discovered things myself. I felt like a student..."

Male (CBL-2)

“...The cases were in our control. We decided what to do. I loved it. Without telling me to be prepared for the course beforehand, you made me get prepared through a practice. I mean, I felt obligatory to do so to make a full sentence. If I could not do anything, I would read the subject of the day for half an hour during the bus ride... First, the time was not enough, then it was satisfactory. In general, this practice was first tiring and required an adaptation process. When I got used to it, the whole process was really enjoyable. I already love anything that encourages students to get part in a practice. The whole control of the process belongs to us and this is effective for self-confidence..."

\subsection{Affective Impact}

Among the students' opinions on the practice of the case-based curriculum in the introduction to educational sciences course, the opinions obtained from the student interviews on the theme of "Affective Impact" and the frequency of these opinions are presented in Table 8.

Table 8 . The opinions of the students on the affective impact of case-based curriculum and their frequency

\begin{tabular}{|c|c|c|c|c|c|c|c|}
\hline \multirow[t]{2}{*}{ THEME } & \multirow[t]{2}{*}{ CODES } & \multicolumn{2}{|c|}{$\begin{array}{l}\text { CBL1 } \\
(\mathrm{n}: 11)\end{array}$} & \multicolumn{2}{|c|}{$\begin{array}{c}\text { CBL2 } \\
(\mathrm{n}: 9)\end{array}$} & \multicolumn{2}{|c|}{$\begin{array}{l}\text { Total } \\
(\mathrm{n}: 20)\end{array}$} \\
\hline & & $\mathrm{f}$ & $\%$ & $\mathrm{f}$ & $\%$ & $\mathrm{f}$ & $\%$ \\
\hline \multirow{6}{*}{$\begin{array}{l}\text { Affective } \\
\text { Impact }\end{array}$} & Loving the course & 8 & 40 & 9 & 45 & 17 & 85 \\
\hline & Raising the interest & 3 & 15 & 2 & 10 & 5 & 25 \\
\hline & Positive self-evaluation & 4 & 20 & 1 & 5 & 5 & 25 \\
\hline & Professional awareness & 7 & 35 & 7 & 35 & 14 & 70 \\
\hline & Positive professional self-efficacy perception & - & - & 2 & 10 & 2 & 10 \\
\hline & Adopting the profession & 3 & 15 & 3 & 15 & 6 & 30 \\
\hline
\end{tabular}

According to Table 8, 17 out of 20 students (85\%) stated that CBL contributed to increase their interest to the course and $14(70 \%)$ stated that it contributed to their awareness towards the teaching profession. In addition, 6 of 20 students $(30 \%)$ stated that they adopted the teaching profession by means of CBL and $5(25 \%)$ stated that their CBL contributed to their positive self-evaluation. One can observe that the frequencies were in parallel with each other, when the frequencies of CBL-1 and CBL-2 were compared.

\subsubsection{Students' Statements Regarding Affective Impact}

Students`opinion about the CBL methods indicates that they tended to have positive attitudes towards lesson. They also stated that $\mathrm{CBL}$ contributed to the adoption of their profession and to gain professional awareness. Direct citations obtained from the views of the students are given below.

Female (CBL-1)

"... I was very happy in the practice of case-based curriculum, because it showed the beauty and the subtleties of my profession. It enabled me to take lessons from the events the students experienced, so I liked the Case-Based Curriculum practice. It caused great changes in my attitude towards teaching and the profession. It helped me to understand the importance of a teacher in a student's life..."

Male (CBL-2)

"...In general, the course was productive. I learned the preliminary information, theories, data etc. about the teaching profession in this course. I felt like a teacher with the approaches in this course for the first time. Therefore, I was happy and excited during the course. Presentation of examples and events, approach to student, presentation and reinforcement of concepts... These were the things that I loved about the practice... I started to love the department which I had not chosen voluntarily..."

\subsection{Social Impact}

Among the students' opinions on the practice of the case-based curriculum in the introduction to educational sciences course, the opinions obtained from the student interviews on the theme of "Social Impact" and the frequency of these opinions are presented in Table 9.

According to the results in Table 9, 18 (90\%) out of the 20 students stated that CBL had a positive effect on socialization and communication skills development and $15(75 \%)$ stated that it supported cooperative working. In 
addition, 7 out of the 20 students (35\%) stated that CBL improved their self-expression skills and $6(30 \%)$ of stated that CBL improved their discussion skills. When the frequencies of CBL1 and CBL2 are compared, frequencies of the CBL2 practice are observed to be higher. Direct citations obtained from the views of the students on the theme of "Social Impact" are given below.

Table 9. The opinions of the students on the social impact of case-based curriculum and related frequency distribution

\begin{tabular}{|c|c|c|c|c|c|c|c|}
\hline \multirow[t]{2}{*}{ THEME } & \multirow[t]{2}{*}{ CODES } & \multicolumn{2}{|c|}{$\begin{array}{l}\text { CBL1 } \\
\text { (n:11) }\end{array}$} & \multicolumn{2}{|c|}{$\begin{array}{c}\text { CBL2 } \\
(\mathrm{n}: 9)\end{array}$} & \multicolumn{2}{|c|}{$\begin{array}{l}\text { Total } \\
(\mathrm{n}: 20)\end{array}$} \\
\hline & & $\mathrm{f}$ & $\%$ & $\mathrm{f}$ & $\%$ & $\mathrm{f}$ & $\%$ \\
\hline \multirow{6}{*}{ Social Impact } & Self-expression & 3 & 15 & 4 & 20 & 7 & 35 \\
\hline & Intra-group information exchange & 1 & 5 & 5 & 25 & 6 & 30 \\
\hline & Improving and steering the discussion skills & 2 & 10 & 4 & 20 & 6 & 30 \\
\hline & Cooperation & 8 & 40 & 7 & 35 & 15 & 75 \\
\hline & Respecting and valuing others' opinions & - & _ & 4 & 20 & 4 & 20 \\
\hline & Positive communication and socializing & 11 & 55 & 7 & 35 & 18 & 90 \\
\hline
\end{tabular}

\subsubsection{Students' Statements Regarding Social Impact}

Students pointed out during the interview that the CBL supports communication and cooperation among students. They also stated that they learned to be respectful of different opinions through the CBL. Direct citations obtained from the views of the students are given below.

Female (CBL-1)

"... We read and evaluated the cases as a group. It is necessary for a group to cooperate to read the cases early and to answer the questions at the end of the case. Working in a cooperative group, we realized that it made our work even easier. It was easier to communicate within the classroom because we had discussions with a group of different people in each lecture... I think that different thinking skills, research and discussion skills were improved for me. Because after reading the case, we had the opportunity to do research on the subject, after discussing the case as a group, there was an atmosphere in which we discussed our different ideas as class ..."

Male (CBL-2)

"...None of us has an individual life. The whole ecosystem is the biggest indicator of collaboration. I really value group works. I believe it is one of the best acquisitions at school to be a healthy individual in society. In our class, even if we did not notice the beginning, the work carried out by at least five people with one piece of paper really adds a lot. The contradictions in that moment are a very nice thing to finally reach a common conviction and I think it is a nice thing to respect the idea that I especially face in the groups I work with. Personally, I learned the names of my classmates thanks to this practice. This bond of respect sets the groundwork for a terrific solid relationship... "

\section{Conclusion and Recommendations}

In this study, the effect of the case-based curriculum on learning levels of the students with two different teaching methods was investigated using the pretest-posttest control group pattern which is one of the semi-experimental research methods. In addition, the students' opinions about the case-based curriculum were asked and reported. In the first experimental group; case-based curriculum developed within the scope of the research was implemented through the presentation of the unit subjects, applying the teaching strategy and using the cases (CBL1). In the second experiment group; case-based curriculum developed within the scope of the research was implemented by ensuring students to reach information through the cases rather than the presentation of the unit subjects by the instructor (CBL2). Conventional education was maintained in the control groups.

Paired sample t-test and Wilcoxon signed ranks test were used to detect whether there is a significant difference between the acquisition scores of first experimental group in which the CBL1 technique is applied and the second experimental group in which the CBL2 technique is applied in the "introduction to educational science" course and the control groups. The results of this study indicate that the difference between the pre-test and post-test scores of the experiment-1 and experiment-2 groups, department of psychological counseling and guidance, department of classroom teaching branch- A and branch-B in which CBL-1 and CBL-2 techniques were used was significant. According to these results, it is seen that the CBL-1 and CBL-2 techniques applied in the experimental groups and the traditional methods applied in the Department of Psychological Counseling and Guidance, Siirt University Department of Classroom Teaching branch-A and branch-B caused significant differences between the pre-test and post-test scores of the students. On the other hand, it was found that the difference between the pre-test and post-test scores of the departments of mathematics teaching, pre-school and social studies teaching in which traditional method was applied was not significant. Therefore, it can be 
said that the traditional methods applied in these classes did not have a significant effect on the learning levels of the students. In addition, it was found that the difference between the mean pre-test and post-test scores for the experimental groups was higher compared to the departments in the control groups. However, this finding does not provide sufficient evidence that CBL-1 and CBL-2 techniques offer a more effective learning environment than the traditional methods. Therefore, in order to investigate the effectiveness of CBL-1 and CBL-2 techniques, one-way ANOVA method was used to detect the difference between the post-test scores of the experimental groups which had a significant difference between the pre-test and post-test scores.

According to one-way ANOVA results which ensures the comparison of the post-test scores of the experimental and control groups, it was found that the difference between the post-test scores of the CBL-1 experimental group and CBL-2 experimental group was not statistically significant. However, it was found that the difference between the post-test scores of the CBL-1 experimental group the other control groups (Siirt university classroom teaching branch-A, Siirt university classroom teaching branch- B and the department of psychological counseling and guidance) was statistically significant. Similarly, it was found that the difference between the post-test scores of the CBL-2 experimental group and the control groups was statistically significant. Although the post-test scores of the CBL-1 experimental group were higher than the CBL-2 experimental group, this difference was not statistically significant. According to these findings, one can conclude that more effective teaching was achieved for the "introduction to educational sciences" course in classes where both the CBL-1 and CBL-2 techniques were applied compared to the classes where traditional methods were applied. As a matter of fact, the studies in the literature have found that the case-based curricula have an enhancing effect on the students' academic achievement compared to the traditional methods (Saral, 2008; Adali, 2005; Ciraj, Vinod and Ramnarayan, 2010; Nelson, 2010; Brown, Pond, \& Creekmore, 2011; Adiga \& Adiga, 2011; Kapti \& Senemoglu, 2015; Taradi \& Taradi, 2016).

Qualitative data regarding the opinions of the students on the contribution of the Case-Based Curriculum to the acquisition of cognitive skills, affective characteristics and social skills in "introduction to educational science" course were detected through content analysis under the themes of "Cognitive Impact", "Affective Impact" and "Social Impact".

According to the findings on the cognitive impact theme, students expressed that CBL contributed to meaningful learning, their learning was more permanent and it steered them to research. In addition, they stated that they actively participated in the process with CBL and, CBL improved their interpretation skills. According to the literature review, it is emphasized that CBL methods increase the academic achievements of the students in different disciplines and facilitate learning (Curran, et al 2008, Nelson, 2010, Taradi \& Taradi, 2016). In addition to increasing academic achievement, it is emphasized that CBL also increases students' high-level cognitive skills such as problem solving and critical thinking (Adali, 2005, Nelson, 2010, Ciraj, Vinod \& Ramnarayan 2010, Kopp, Hasenbein \& Mandl, 2014, Ganiron, 2014).

On the other hand, frequencies of the CBL2 practice were observed to be higher when the frequencies of CBL-1 and CBL-2 were compared. However, some of the students from the CBL-2 group stated that they had problems in managing time effectively. It can be said that the CBL-2 technique has a higher cognitive effect on the students, even though the students in the CBL-2 class stated that they had problems managing time effectively. According to the opinions of the students, they expressed that they had problems in managing time effectively in both CBL methods. As a matter of fact, Nelson (2010) stated that the main reasons for the lower preference of CBL techniques compared to traditional methods are some features of CBL such as being time consuming and costly, and requiring skill and experience to be implemented.

According to the opinions of the students on the theme of "affective impact" among case-based learning techniques, a large majority of students stated that CBL contributed to increase their interest to the course, and awareness towards the teaching profession. Similarly, some students stated that they adopted the teaching profession by means of CBL and, CBL contributed to their positive self-evaluation. Comparing the frequency distributions of CBL-1 and CBL-2, it was observed that students expressed similar opinions in the classrooms where both techniques were used. Therefore, it can be deduced that the affective impact of CBL-1 and CBL-2 techniques on students is similar. In parallel with the results of the present research, it was stated that students generally adopted the CBL techniques, they had the perception that they learned more with the CBL techniques, and their interest and motivation increased because they related the subjects to daily life (Ertmer, Newby \& MacDougal, 1996; Flynn \& Klein, 2001; Herreid, 2005; Curran, Sharpe, Forristall, \& Flynn, 2008; Ciraj, Vinod \& Ramnarayan 2010; Yalçınkaya, 2010; Razzouk, 2011; Çelik, Çevik \& Haşlaman, 2012).

Finally, when the opinions of the students on the theme of "social impact" were examined, majority of the students expressed that CBL had a positive effect on socialization and communication skills development and CBL supported cooperative working. Some of the students expressed that CBL techniques improved their self-expression and 
discussion skills. Previous studies have emphasized that the CBL techniques improve learning within groups, student interactions in a group and improve socialization by means of this interaction (Curran et al, 2008; Dupuis \& Persky, 2008; Razzouk, 2011; Kopp, Hasenbein \& Mandl, 2014). When the frequencies of CBL1 and CBL2 on the codes detected in line with the students' opinions were compared, the frequencies of the CBL2 practice were observed to be higher. Therefore, one can conclude that that the social effect of the CBL-2 technique on students was higher than the CBL-1 and traditional methods.

The results indicate that the case-based curriculum developed in this study made substantial contribution to pre-service teachers' high-level thinking skills, the acquisition of skills on the basis of practice and the positive attitudes towards teaching profession. However, it is necessary to investigate the reflection of this study on different socio-cultural and larger working groups. It is believed that more comprehensive findings can be obtained by means of further studies and educationalists will be given the opportunity to better understand the nature of learning and teaching. In addition, within the scope of the other courses in different departments of the Faculty of Education, CBL can be taken as a basis for developing curricula and the effectiveness of these curricula can be viewed in terms of improving the cognitive, social and affective skills of students. Moreover, by conducting longitudinal research, it is possible to investigate in depth how students develop their attitudes towards their professions. It is also recommended to investigate the effect of different CBL-based methods on students` learning process, attitudes towards subject and their relationship with other students at different education levels.

\section{References}

Adal1, B. (2005). Effect of case-based method on the 5th grade elementary school students akademic achievement and attitudes toward science while teaching viruses, bacteries, fungi and protists. Unpublished Master's Thesis. Mustafa Kemal University, Hatay.

Adiga, U., \& Adiga, S. (2011). Case based learning in biochemistry. International Journal of Pharma and Bio Sciences, 2(2), 332-336.

Alvarez, M. C. (1990). Case-based instruction and learning: An interdisiplinary project. 34th Annual Meeting of the College Reading Association. Nashville, TN, 2-4 November, 1990.

Barrows, H. S. (1986). A taxonomy of problem-based learning methods. Med. Educ., 20(6), 481-486. https://doi.org/10.1111/j.1365-2923.1986.tb01386.x

Biggs, J., \& Tang, C. (2007). Teaching for quality learning at university. England: Open University Press. McGraw-Hill Education.

Bowie, C. M., Voss, J., \& Aretz, H. T. (2009). Case method teaching: An effective approach to integrate the basic and clinical sciences in the preclinical medical curriculum. Medical Teacher, 31, 834-841. https://doi.org/10.1080/01421590902922904

Brown, S. D., Pond, B. B., \& Creekmore, K. A. (2011). A case-based toxicology elective course to enhance student learning in pharmacotherapy. American Journal of Pharmaceutical Education, 75(6), 1-7. https://doi.org/10.5688/ajpe756118

Çam, A. (2009). Effectiveness of case-based learning instruction on students' understanding of solubility equilibrium concepts. Unpublished Doctoral Disssertation. ODTÜ, Ankara.

Çelik, S., Çevik, Y. D., \& Haşlaman, T. (2012). Reflections of prospective teachers regarding case-based learning. Turkish Online Journal of Qualitative Inquiry, 3(4), 64-78.

Choi, I., \& Lee, K. (2009). Designing and implementing a case-based learning environment for enhancing ill-structured problem solving: classroom management problems for prospective teachers. Educational Technology Research and Development, 57, 99-129. https://doi.org/10.1007/s11423-008-9089-2

Ciraj, A. M., Vinod, P., \& Ramnarayan, K. (2010). Enhancing active learning in microbiology through case based learning: Experiences from an Indian medical school. Indian Journal of Pathology and Microbiology, 53(4), 729-733. https://doi.org/10.4103/0377-4929.72058

Curran, V. R., Sharpe, D., Forristall, J., \& Flynn, K. (2008). Student satisfactions and perceptions of small group process in case-based interprofessional learning. Medical Teacher, 30, 431-433. https://doi.org/10.1080/01421590802047323

Dupuis, R., \& Persky, A. M. (2008). Instructional design and assessment; Use of casebased learning in a clinical pharmacokineticks course. American Journal of Pharmaceutical Education, 72(2), 1-7.

https://doi.org/10.5688/aj720229 
Elksnin, L. K. (1998). Use of the case method of instruction in special education teacher preparation programs: A preliminary investigation. Teacher Education and Special Education, 21(2), 95-108. https://doi.org/10.1177/088840649802100204

Ertmer, P. A., Newby, T. J., \& MacDougal, M. (1996). Students' responses and approaches to case-based instruction: The role of reflective self-regulation. American Educational Research Journal, 33(3), 719-752. https://doi.org/10.3102/00028312033003719

Flynn, A. E., \& Klein, J. D. (2001). The influence of discussion groups in a case-based learning environment. Educational Technology Research and Development, 49(3), 71-86. https://doi.org/10.1007/BF02504916

Fossey, R., \& Glover, S. (2006). Writing the undisguised case. Journal of Cases in Educational Leadership, 9(1), 1-11. https://doi.org/10.1177/1555458905284835

Ganiron, Jr., T. U. (2014). The impact of higher level thinking on students' achievement toward project management course. International Journal of Service, Science and Technology, 7(3), 217-226. https://doi.org/10.14257/ijunesst.2014.7.3.19

Herreid, C. F. (1994). Case studies in science: A novel method of science education. Journal of College Science Teaching, 23, 221-229.

Herreid, C. F. (2005). Using case studies to teach science. American Institute of Biological Science. ActionBioscience.org (Online Dergi). Erişim Tarihi: 23.09.2017. http://files.eric.ed.gov/fulltext/ED485982.pdf

Horzum, M. B., \& Alper, A. (2006). The effect of case based learning model, cognitive style and gender to the student achievement in science courses. Ankara University Journal of Faculty of Educational Sciences, 39(2), 151-175. https://doi.org/10.1501/Egifak_0000000141

İlhan-Beyaztaş, D. (2014). Learning approaches of successful students' and their suggestions about effective learning. Unpublished Doctoral Disssertation. Hacettepe University, Ankara.

Kapti, S. B., \& Senemoglu, N. (2015). Effectiveness of Case Based Curriculum. Illköğretim Online, 14(3), 899-913.

Kopp, B., Hasenbein, M., \& Mandl, H. (2014). Case-based learning in virtual groups - collaborative problem solving activities and learning outcomes in a virtual professional training course. Interactive Learning Environments, 22(3), 351-372. https://doi.org/10.1080/10494820.2012.680964

Levin, B. B. (1995). Using the case method in teacher education: The role of discussion and experience in teachers' thinking about cases. Teaching \& Teacher Education, 11(1), 63-79.

https://doi.org/10.1016/0742-051X(94)00013-V

McNaught, C., Lau, W. M., Lam, P., Hui, M. Y. Y., \& Au, P. C. T. (2005). The dilemma of case-based teaching and learning in science in Hong Kong: Students need it, want it, but may not value it. International Journal of Science Education, 27(9), 1017-1036. https://doi.org/10.1080/09500690500068618

McWilliam, P. J. (1992). The Case Method of Instruction: Teaching Application and Problem-Solving Skills to Early Interventionists. Journal of Early Intervention, 6(4), 360-373. https://doi.org/10.1177/105381519201600407

Miles, M. B., \& Huberman, A. M. (1994). An expanded sourcebook qualitative data analysis. London: SAGE Publications.

Milner, M., \& Wofler, T. (2014). The use of decision cases to foster critical thinking in social work students. Journal of Teaching in Social Work, 34(3), 269-284. https://doi.org/10.1080/08841233.2014.909917

Nelson, T. N. (2010). Case-based learning (CBL) in selected physical therapy curricula and its perceived effectiveness by students, faculty, and administration. Unpublished Doctoral Disssertation. University of New Orleans, New Orleans, LA.

Razzouk, R. (2011). The effects of case studies on individual learning outcomes, attitudes toward instruction, and team shared mental models in a team-based learning environment in an undergraduate educational psychology course. Unpublished Doctoral Dissertaion. Florida State University, Florida.

Roche, V. F., Aitken, M. J., \& Zito, S. W. (1999). Evaluation of computerized medicinal chemistry case study modules as tools to enhance student learning and clinical problem-solving skills. American Journal of Pharmaceutical Education, 63(3), 289-295.

Saral, S. (2008). The effect of case based learning on tenth grade students' understanding of human reproductive system and their perceived motivation. Unpublished Master's Thesis. ODTÜ, Ankara.

Smith, G. (1987). The use and effectiveness of the case study method in management education-A critical review. 
Management Education and Development, 18(1), 51-61. https://doi.org/10.1177/135050768701800107

Taradi, S. K., \& Taradi, M. (2016). Making physiology learning memorable: a mobile phone-assisted case-based instructional strategy. Advances in Physiology Education, 40, 383-387, 2016. https://doi.org/10.1152/advan.00187.2015

Tavşancıl, E., \& Aslan, A. E. (n.d.). Sözel, yazılı ve diğer materyaller için içerik analizi ve uygulama örnekleri. no location information.: epsilon yayınevi.

Wassermann, S. (1994). Introduction to case method teaching: A guide to the galaxy. New York: Teachers College Press.

Weil, S., McGuigan, N., \& Kern, T. (2011). The usage of an online discussion forum for the facilitation of case-based learning in an intermediate accounting course: A New Zealand case. Open Learning: The Journal of Open, Distance and e-Learning, 26(3), 237-251.

Yalçınkaya, E. (2010). Effect of case based learning on 10th grade students' understanding of gas concepts; Their attitude and motivation. Unpublished Doctoral Disssertation. ODTÜ, Ankara.

Yıldırım, A., \& Şimşek, H. (2008). Sosyal bilimlerde nitel araştırma yöntemleri. Ankara: Seçkin Yayıncılık.

\section{Copyrights}

Copyright for this article is retained by the author(s), with first publication rights granted to the journal.

This is an open-access article distributed under the terms and conditions of the Creative Commons Attribution license which permits unrestricted use, distribution, and reproduction in any medium, provided the original work is properly cited. 